\title{
Uncertainties, Knowledge, and Futures in Foresight Studies A Case of the Industry 4.0
}

\author{
Andrzej Magruk \\ Assistant Professor, a.magruk@pb.edu.pl \\ Bialystok University of Technology, 45A, Wiejska Street, 15-351 Bialystok, Poland
}

\begin{abstract}
$\mathrm{T}$ he main purpose of this publication is an attempt to treat the phenomenon of uncertainty as one of the main research subjects in futures studies and not as the background for futures research - by answering the following research question: "What is the methodical relationship between the scope of the uncertainty phenomenon and the levels of knowledge and types of futures in the foresight approach?" This study uses the results of the analysis and criticism of the literature as the main research method. On this basis, deductive reasoning was carried out. The types of futures and the scope of uncertainty allowed to the author to define scale of knowledge levels. This paper has attempted to draw together three methodological fields: uncertainty, foresight, and knowledge. The author analyzed the complex relations

among the above areas on the basis of their characteristics, which are extensions of existing concepts available in the literature. Conclusions from the results presented in this article can be a valuable contribution to the development of the area of futures management. In the management of complex systems (such as Industry 4.0), from the foresight methodological point of view, it seems relevant to determine which specific uncertainties can be managed by which classes of foresight methods, and which foresight methods are determined by what level of knowledge. The results of the research presented in this publication may be used for creating a research methodology for technological foresight projects and as a complementary element of research devoted to the issues of the development of modern technologies, which include Industry 4.0.
\end{abstract}

\section{Keywords:}

uncertainty; knowledge; futures; foresight; method; Industry 4.0
Citation: Magruk A. (2020) Uncertainties, Knowledge, and Futures in Foresight Studies - A Case of the Industry 4.0. Foresight and STI Governance, vol. 14, no 4, pp. 20-33. DOI: $10.17323 / 2500-2597.2020 .4 .20 .33$ 
A $\mathrm{t}$ the beginning of the last century, it was noticed that efforts to make social life more rational generated unintended consequences such as increased uncertainty [Poli, 2017]. From the 1970s and 1980s, new perspectives appeared related to the phenomenon of uncertainty, especially in several areas that deal with human interactions and modern complex technologies (e.g., economics, large-scale processes and energy technologies, systems engineering, management science, computer science, and artificial intelligence) [Smithson, 1989].

Many of today's uncertainties (regional, national, global) are systemic in nature, being one of the most important features of many areas of social and economic life, especially in the context of futures management. Nowadays, one of the most popular approaches in many developed economies is the socalled Industry 4.0. In many respects, this idea, due to its modernity (its beginning dates back to 2011), innovativeness by transforming the way goods are designed, manufactured, delivered and paid for [Hofmann, Rüsch, 2017] and the systemic approach (of scale and dimensions, so far not used until now), is burdened with a high degree of uncertainty [Magruk, 2016]. For example, in the context of the development of a new kind of entrepreneurship, there is now a high level of uncertainty about what we can expect from the challenges and opportunities arising from the shifting of the border between human and machine tasks and algorithms [Ansari et al., 2018]. Another area of uncertainty that is inherent to Industry 4.0 is the problem of the veracity of data, especially big data, that is generated throughout the whole process of managing Industry 4.0. Uncertainty exists in every phase of big data learning and comes from many different sources, such as data collection, concept variance, and multimodality [Hariri et al., 2019].

The management of such systems enforces the use of complex and innovative research approaches (focusing on interdisciplinary fields and problems [Sokolov, Chulok, 2012]), as well as those in the futures context, generating new theories of management [Shepherd, Suddaby, 2017]. Such approaches undoubtedly include well-designed foresight methodologies, focusing on interdisciplinary fields and cross-issue problems, creating the ability to plan different futures based on specific needs or required outcomes [Jemala, 2010].

At the end of the 20th century, foresight became an important instrument for long-term problems related to risk and uncertainty [Jenssen, 2010; Kononiuk et al., 2017] as a consequence of globalization and unprecedented technological progress [Jemala, 2010].

Despite the fact that foresight research tries to steer a course between the unsettling uncertainty and unpredictability of the future and the need for data, information, and knowledge to shape this future [UNDP, 2018], until now uncertainty was not main research object but acted as the background for fu- tures research. The main purpose of this publication is an attempt to change this perspective - to treat uncertainty as the one of main research subjects in futures studies - by trying to solve a research problem related to the scope of uncertainty versus the level of knowledge and types of future shaping the methodology of foresight research. In the author's opinion, in complex systems (in this case this means Industry 4.0 ), from the foresight methodological point of view, it seems relevant to determine which kinds of future and levels of knowledge will be appropriate for the analysis of the scope of uncertainties.

\section{Methodology}

This study uses the results of an analysis and criticism of the literature as the main research method. Upon this basis, conceptual modeling was performed.

Both the human ability to understand the processes of change, the indication of cause-and-effect relationships, and plan for the future requires knowledge characteristic of foresight research. When uncertainty is expressed in connection with a desired outcome (this is very typical for foresight research) is it more positively evaluated than when it is expressed in terms of an undesired outcome [Smithson, 1989]?

Knowledge generated in foresight studies is characterized by a high degree of uncertainty and complexity. However, the quality of foresight knowledge is most often analyzed in terms of its reliability than the accuracy of the predictability of certain events [Guimaraes et al., 2006].

As mentioned in the introduction, it should be stated that in the foresight studies, the uncertainty phenomenon is most often the background for these studies and not its main subject. However, there are methodical areas of foresight in which the problem of uncertainty is being studied on a wider scale [Magruk, 2017a] through approaches such as scenario analysis [Ringland, 1998; Kononiuk, Nazarko, 2014], the cone of the future [Amara, 1974; Hancock, Bezold, 1994; Kononiuk, Nazarko, 2014; Voros, 2017], the cone of uncertainty [Magnus, 2012], and strategic foresight [Courtney et al., 1997; Courtney, 2001]. The ideas mentioned above constitute a substantive basis for the study of uncertainty as the main object in foresight research.

Uncertainty in the modern era is the result of the complex interactions of forces of many kinds: technological, social, political, economic, and environmental [Ringland, 1998; Chodakowska, Nazarko, 2017].

Every theory of knowledge draws a distinction between knowledge and ignorance, and most do so between ignorance in the sense of incomplete knowledge and ignorance in the sense of erroneous belief [Smithson, 1989].

In the taxonomy of ignorance proposed by Smithson, uncertainty is only one of the types of ignorance (Figure 1) [Smithson, 1989]. In this article, a different 


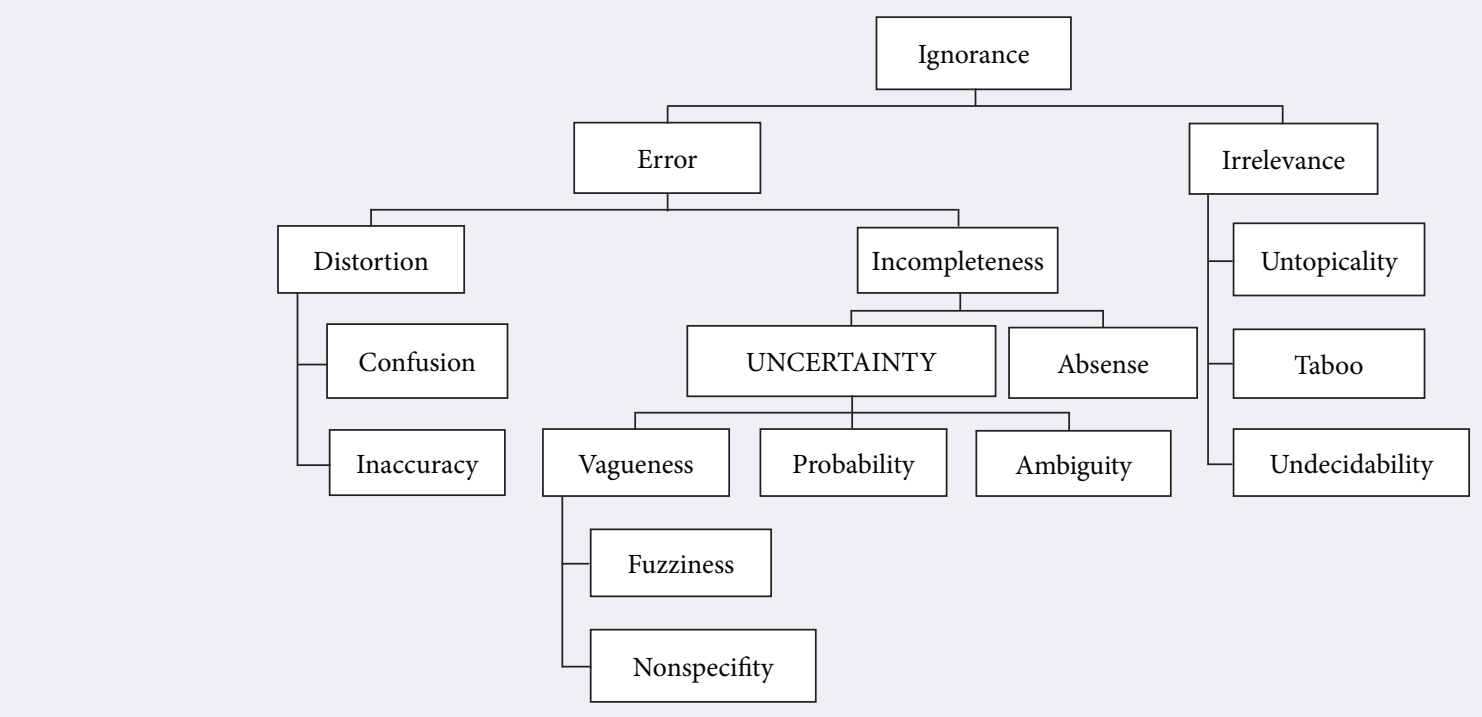

Source: [Smithson, 1989].

perspective is used. Uncertainty is the subject of the study in relation to the levels of knowledge (as opposed to ignorance).

It should be stressed that uncertainty can be considered from a much larger number of points of view than shown in Figure 1. There are many definitions (Table 1) and typologies of uncertainty developed for various purposes [Walker et al., 2003; Lindley, 2013; Jalonen, 2012; van der Sluijs et al., 2004; Funtowicz, Ravetz, 1990; Magruk, 2016; Bombola, 2014; Jedralska, Czech 2011; Wawiernia, 2013]. In this article the author presents an innovative proposal to enlarge this spectrum with new scopes in relation to levels of knowledge and types of future.

In this publication, uncertainty is treated as a phenomenon that arises from two sources. The first source is subjective (epistemic) and results from selfknowledge (lack of knowledge) about the information on the basis of which decisions are formulated, but which (uncertainty) may be reduced by additional research [Gawet et al., 2015]. The second source of uncertainty is objective (ontological, aleotaric) and results from the stochasticity of the nature of the examined object and is irreducible [Aven, 2010]. The ontological nature of uncertainty refers to such categories as: existence and its ways, essence, subject and its properties, causality, time, space, necessity, and possibility [Nja et al., 2017].

Self-knowledge about the decision situation in the context of uncertainty refers to three aspects important from the future research point of view of [Kaivooja et al., 2004]: 1) knowledge, 2) predictability, and 3) time.

Knowledge, in the context to uncertainty, is the result of two components: awareness of self and knowledge of the world. It can be manifested in the following ways [Atherton, 2013; Bojarski, 1981] (Figure 2):

- the researcher knows of that which he is sure corresponds to a high level of predictability;

- researcher knows that he does not have enough knowledge - corresponds to a medium level of predictability;

- the researcher does not know how he knows - or cannot express it-corresponds to a very low level of predictability;

- the researcher does not know that he does not have sufficient knowledge and is under the mistaken belief that he knows enough - corresponds to a "zero" level of predictability.

With the widening of the time horizon there is a correlation between the increase in the level of uncertainty and the decrease in predictability (Figure 3 ). In a short period of time, predictability is high, which determines the application of forecasting models (F). In the medium term, the level of predictability and uncertainty determines the use of scenario and simulation methods (S). In the very distant future, we are dealing with a very deep uncertainty, and all attempts at prediction can only be based on hope $(\mathrm{H})$ [Kaivooja et al., 2004].

For distant time horizons, the degree of complexity of the features, structures, and behaviors of the examined systems is increasing. Knowledge relating to these issues is becoming increasingly blurred, contributing to the deepening of uncertainty [Magruk, 2017b].

Industry 4.0 - the forerunner of the fourth industrial revolution - is such a complex system. It is a vision in which the real world will connect fully with the 


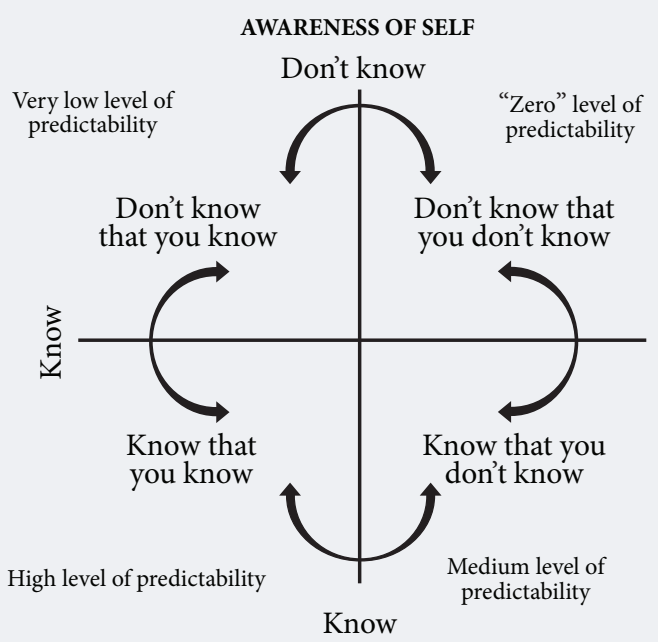

Source: [Atherton, 2013].

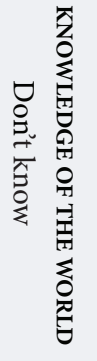

Sources: [Kaivo-oja et al., 2004; Magruk, 2017a]. digital environment. Universality in the applications of Industry 4.0 including the Internet of Things, Big Data, cloud manufacturing, inter-machine communication, and cyber-physical systems, using interoperability, decentralization, and the full virtualization will certainly affect the course of many phenomena (economic, social, technological, etc.) [Siderska, Jadaan, 2018], while the direction, strength, and intensity of these changes are increasingly often becoming unpredictable (the not fully developed concept of Indus-

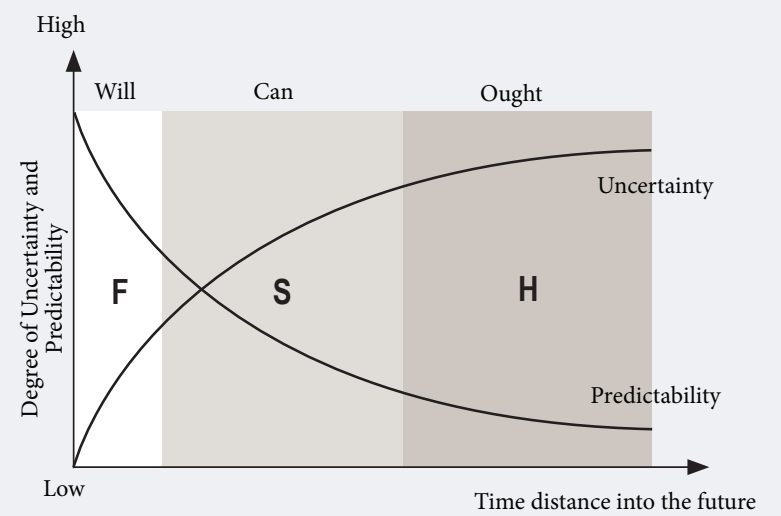

try 4.0 is already a driving force for its new generations, i.e. Industry 5.0 [Nahavandi, 2019] or Industry X.0 [Abood et al., 2017; Schaeffer, 2017]). The above facts mean that this vision is burdened with a high level of uncertainty in many aspects from the level of design to the level of use [Magruk, 2016].

The occurrence of the uncertainty phenomenon in the context of the future analysis of the development of such complex systems (as Industry 4.0) is broadly influenced by the following factors [Bojarski, 1981]:

\section{Table 1. Selected Interpretations of the Uncertainty Phenomenon}

\begin{tabular}{|c|c|c|}
\hline Area of study & Definitions of uncertainty & чee ecae \\
\hline Theory of economics & $\begin{array}{l}\text { Uncertainty is a subjective measure that correlates with objective } \\
\text { risk; a measure of uncertainty is the probability of the occurrence } \\
\text { of a specific event }\end{array}$ & Allan Willett, Frank Knight \\
\hline Game theory & $\begin{array}{l}\text { Uncertainty occurs when only a few alternatives of results are } \\
\text { known, without the probability of their occurrence }\end{array}$ & Wiesław Samecki \\
\hline Quantum physics & $\begin{array}{l}\text { Uncertainty is determined by the principle of indeterminacy - } \\
\text { there is a fundamental limitation of the possibility of simultaneous } \\
\text { measurement with the infinite accuracy of specific dynamic } \\
\text { quantities. }\end{array}$ & Werner Heisenberg \\
\hline Systems theory & $\begin{array}{l}\text { Uncertainty results from the inability to accurately determine } \\
\text { all states of the elements of large dynamic systems and their } \\
\text { relationships in the past and in the future }\end{array}$ & Wlodzimierz Bojarski, Jan Zieleniewski \\
\hline Foresight & $\begin{array}{l}\text { An important feature of foresight is accepting the fact of } \\
\text { uncertainty, trying to understand it and making it a part of } \\
\text { thinking about the future }\end{array}$ & $\begin{array}{l}\text { Dana Mietzner, Guido Reger, Angela } \\
\text { Wilkinson }\end{array}$ \\
\hline $\begin{array}{l}\text { Theory of decision } \\
\text { making }\end{array}$ & $\begin{array}{l}\text { The distinction between determinism (confidence), probability } \\
\text { (objective uncertainty) and fuzzyness (subjective uncertainty) }\end{array}$ & Mirosław Bereziński, Jerzy Hołubiec \\
\hline Cosmology & $\begin{array}{l}\text { Uncertainty results from the singularity of the expansion of the } \\
\text { universe and the collapse of massive stars }\end{array}$ & $\begin{array}{l}\text { Albert Einstein, Andrew Strominger, } \\
\text { Malcolm Perry }\end{array}$ \\
\hline $\begin{array}{l}\text { Theory of } \\
\text { information }\end{array}$ & $\begin{array}{l}\text { Uncertainty should be defined as entropy, resulting from } \\
\text { information overload }\end{array}$ & Claude Shannon \\
\hline $\begin{array}{l}\text { Epistemology } \\
\text { (researchers } \\
\text { perspective) }\end{array}$ & $\begin{array}{l}\text { Uncertainty results directly from the ignorance of the researcher } \\
\text { regarding the cognitive process and the measurement result }\end{array}$ & Kazimierz Ajdukiewicz \\
\hline
\end{tabular}


- the multiplicity of possible structures, their high complexity, and variability;

- number and strength of internal links of the system;

- insufficient knowledge of the surrounding environment;

- behavior of persons and institutions managing the system in the context of the potential to go beyond known rules;

- ignorance of new potential rules and their scope;

- length of the considered time horizon.

Factors that generate uncertainty in particular in the area of Industry 4.0 are [Magruk, 2016; Cividino et al., 2019]:

- ignorance of new potential rules and their scope;

- the very large scale of mutual relations between all entities contributing to the ecosystem Industry 4.0

- creating new, previously unknown business models of cooperation and new value creation chains;

- the integration of new IT systems with old systems not designed for the Internet of Things;

- the creation of jobs by Industry 4.0 with new competences, e.g., for robots;

- the increase in the complexity of manufactured parts;

- the digitization of business processes goes beyond the boundaries of closed facilities (factories), e.g., virtual fleets, and includes everywhere and anytime.

According to P. Schwartz uncertainty is the "new normal" in today's rapidly changing times [Schwartz, 2012]. This is the level of decision and uncertainty that called "postnormal science" [Funtowicz, Ravetz, 1990]. Selected elements of this concept regarding the relationship of uncertainty to ignorance [Aven, 2013] are used in the main chapter of this article.

\section{Research Findings}

The author proposes to use the concept of the matrix of uncertainties, futures, and knowledge (Figure 4, which basic skeleton in the form of a "future cone" was developed by J. Voros [Voros, 2017] based on among others the work of Hancock and Bezold [Hancock, Bezold, 1994]) in the research of the future (in particular in foresight) and uncertainty. The other important ideas taken into account in the process of building the "cone of futures \& possibilities" include the "cone of plausibility" [Taylor, 1990], the future cone, and ignorance and uncertainty matrix [Sardar, Sweeney, 2016], cone of possibility space [Candy, 2010], the idea of the "future light cone" [Hawking, 1988], and the "cone of uncertainty and possibilities" [Magnus, 2012].

The more distant time horizon, the worse the quality and resources of knowledge (the higher level of ignorance) and the greater the uncertainty (its scope and range). At the same time, with a larger area of uncertainty and an increase in the indeterminacy of the dynamics of changes in the structures of the observed system, we are dealing with different types of futures. In a completely deterministic system, if it was known what was going on during the initial state of uncertainty, it would be possible to predict with a high probability the future developments of the occurrences we would have to deal with [Magruk, 2017b]. In nondeterministic systems, the past and present events determine only the distribution of the probability of possible states in the future [Heller, 2016].

This approach (shown in Figure 4) makes it possible to identify (and, as a consequence, manage) selected types of uncertainty. Thanks to this approach, it is possible to change the research perspective in which the kinds of the future (types of alternative futures) characteristic of the "future cone" can become a background for uncertainty research.

Below are presented the characteristics of the types of uncertainties in relation to particular levels of knowledge corresponding to the particular types of the future.

Zero scope of uncertainty with nomological knowledge vs. predicted future.

It is a very rare situation in which uncertainty is at a zero level, i.e., we can say with about 100 percent certainty, phenomena are based on total determinism. In this case, one can speak about a situation related to Laplace's doctrine of the nineteenth century, namely that the universe is completely determined [Magruk, 2017b]. It is the future that someone claims 'will' happen. This category of the future corresponds with the possibility of the occurrence of the "black elephants" [Sardar, Sweeney, 2016] - events which are extremely likely and widely predicted by experts. Knowledge in this case is based on total trust, it has a nomological character referring to the fundamental laws governing a given reality. There is a very high awareness of possessed and unqualified knowledge. This knowledge is based upon the relationship with dogmatic philosophers such as Plato or Locke who needed absolute certainty about knowledge [Smithson, 1989].

Surface scope of uncertainty with plain knowledge vs. projected future.

This uncertainty refers to a certain tendency that can be managed to some degree with adequate knowledge and foresight tools. Projected future is characteristic of simple prognostic studies in which the forecasting is based upon the extrapolation of historical data [Pieriegud, 2015]. Plain knowledge is single-person default knowledge. The awareness of knowledge is high - you know what you know, you know what you are not sure about, and what you do not know. Ignorance and uncertainty can be minimized through learning, research, appreciating the viewpoints of 


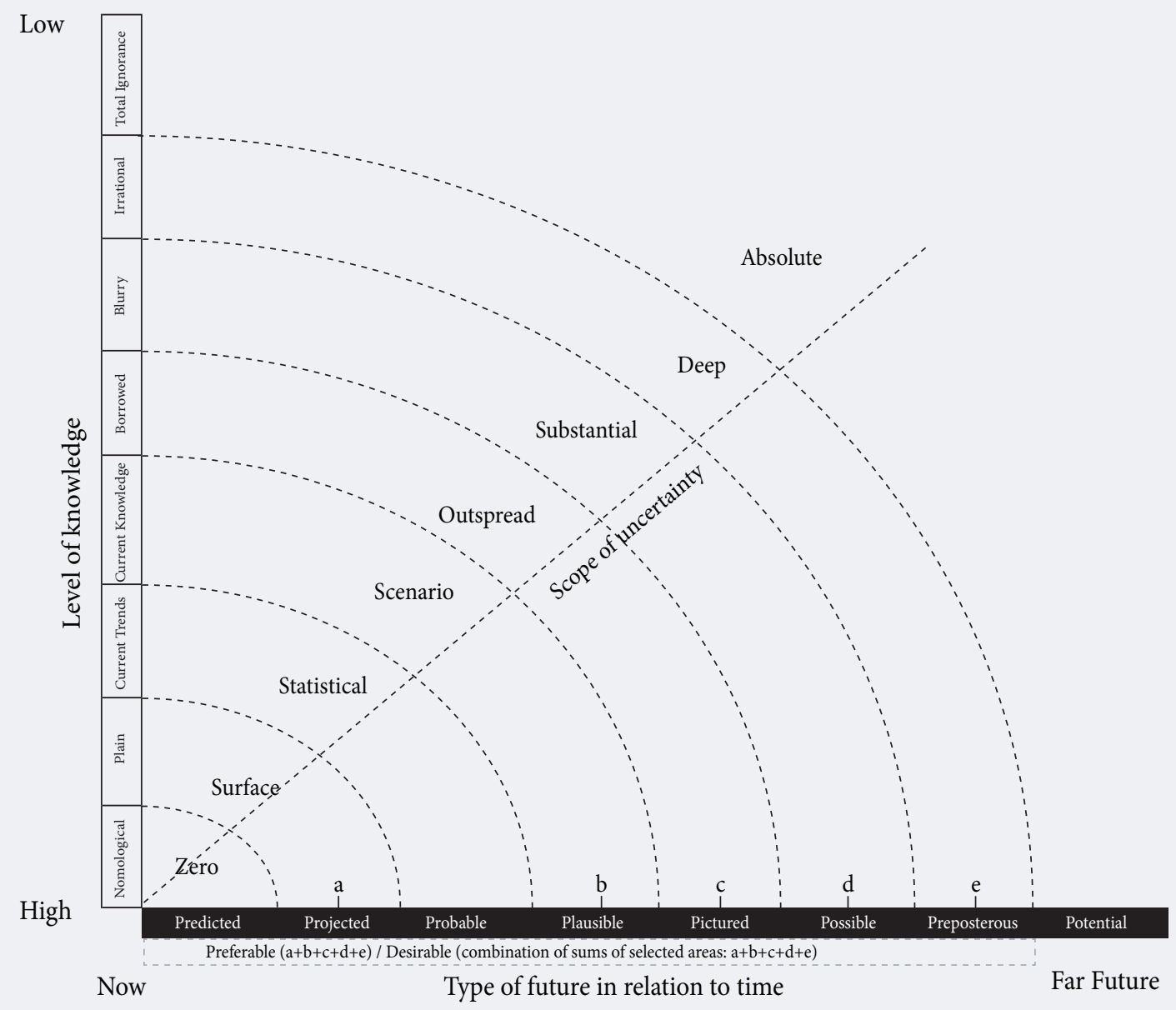

Source: compiled by the author.

others, and asking the right questions as well as by processing the available information to produce hypotheses that could shed some light on what we are seeing [Sardar, Sweeney, 2016].

Statistical scope of uncertainty with current trends vs. probable future

In this field we are dealing with statistical uncertainty, it means that uncertainty is based on well described functional relationships. The level of knowledge is closely related to the awareness of and knowledge about current trends and megatrends. Nevertheless, although megatrends are certainties, they always contain elements of uncertainty. All outcomes (expressed stochastically) and all probabilities are known [Refsgaard et al., 2012]. This kind of future expresses what we know with great confidence about the future [Larsen, 2006]. An example of statistical uncertainty is the measurement of uncertainty associated with a sampling error, or an inaccuracy or imprecision in the measurements [Walker et al., 2003];

Scenario scope of uncertainty with current knowledge vs. plausible future

Knowledge is based on our current understanding of how the world works [Voros, 2017]. In this case the whole range of outcomes of plausible futures and probabilities is unknown [Refsgaard et al., 2012]. Plausible futures do not forecast what will happen in the future; rather they indicate what could happen [Voros, 2017; Walker et al., 2003]. Scenario uncertainty is related to the external (often future) environment of a system and its effects upon the system. Scenario uncertainty implies that there is a range of discrete possible outcomes, but the mechanisms leading to these outcomes are not well understood without the allocation of their likelihood [Walker et al., 2003]. 
Outspread scope of uncertainty with borrowed knowledge vs. pictured future

Knowledge is based on the conviction (or on the naïve assumption) that solutions proposed by someone will be analogous in reality. Uncertainty is focused on a broad range of alternatives (borrowed from advertising, corporate visions, popular 'futurology' and science fiction novels, films, television shows and projects from other places successfully completed). This range, despite its large capacity, is defined by limited numbers of key variables. The pictured future is similar to the "familiar future" [Sardar, Sweeney, 2016] and "used future" [Inayatullah, 2008] - one of the six basic concepts of futures thinking. It is someone's image of the future, someone's desired future or is it unconsciously borrowed from someone else from a scientific point of view, in the context of a literature review.

\section{Substantial scope of uncertainty with blurry knowledge vs. possible future}

Knowledge about the general direction of change cannot be achieved at present (it is very blurred based on a broad range of alternatives and a plethora of possible avenues of development). This creates an awareness of what we do not know and what we must seek to know in the future. Uncertainty is due to common complexity, chaos, and contradictions of analyzed pieces of information. Uncertainty is related to a complex problem - we are aware that we do not have enough knowledge - we do not know what we do not know - but we can still grasp it to some extent [Sardar, Sweeney, 2016]. There is a thin line between pictured and possible future, but there is a difference based on the fact that in the pictured future we rely upon the already described (by someone) examples and imagined alternatives. In the example of possible future, we can come up with the future ourselves.

\section{Deep scope of uncertainty with irrational knowledge vs. preposterous future}

You do not know what you do not know, but you are under the mistaken belief (based on existing paradigms and modes of knowing, being, and doing) that you know enough. It is knowledge that goes beyond the framework of conventional thought, that does not allow us to focus on or think about. This knowledge requires radically new ways of thinking. Uncertainty is deep because it results from the unawareness of the direction, dimension, and impact of change, and also from the fact we are incapable of knowing what is happening to the system because our worldview or epistemology is totally inadequate. Sardar and Sweeney describe this preposterous future as "unthought future(s)". Is not unthinkable (or not expected or anticipated), but rather its horizon is populated with seemingly infinite alternative futures [Sardar, Sweeney, 2016].
Absolute scope of uncertainty with total ignorance vs. potential future

Knowledge has a zero level (total ignorance), it refers to issues that cannot be imagined. "Total ignorance" is an ignorance that cannot be classified into any type of ignorance described by Smithson [Smithson, 1989]. It is ignorance which is beyond the scope of scientific, logical, mathematical, or otherwise 'proper' analysis just because we cannot imagine a future does not mean it cannot happen [Voros, 2017]. Absolute uncertainty is due to inherent (ontological) variability. This uncertainty is non-reducible. This is the scope of uncertainty characteristic for Pyrrhonist or complete scepticism. Complete scepticism maintains that nothing can be certain, nor can anything be known because no one is justified or reasonable in their assertions about reality [Smithson, 1989]. The potential future is undetermined and 'open' and therefore not inevitable or 'fixed' [Voros, 2017].

It is not always easy to distinguish between these categories of uncertainty; it is often a matter of convenience and assessment related to the characteristics of the problem under study and the current state of knowledge or ignorance [Walker et al., 2003].

The absolute future of the event under investigation is reflected by a set of all events ( $a$ or/and b or/and $\mathrm{b}$ or/and b/and c and/or d or/and e) with which the human being can (but does not have to) interact. The author proposes dividing the preferred future into sub-areas: a, b, c, d, e, characteristic for particular types of uncertainty and types of knowledge, which become preferable only with a specific configuration of factors as the future sum: from a to e, while in other combinations one receives a desirable form of future, characteristic of those found in foresight research.

The author used what is available in the literature in this study, a 10-class classification of foresight methods (Table 2) [Magruk, 2011].

In the author's opinion, in order to minimize the uncertainty phenomenon in predictive studies, it is necessary to take into account the properties of the methods selected for the study (Table 2), which are strongly reflected in the form of the explored type of the future and the level of knowledge they provide (Table 3). This selection was made on the basis of an analysis of the characteristics of individual foresight research methods and the author's experience resulting from his active participation in many foresight initiatives.

The most characteristic approach for foresight research methodology is the selection of appropriate research methods to create desirable futures [Magruk, 2013]. In the author's opinion, the results shown in Table 3 can be helpful for choosing appropriate foresight methods in a situation when we know with what type of future we are dealing with. Knowledge about the type of future may be a derivative of the formulated goals of research in a specific area (be- 
Table 2. Classification of Foresight Research Methods

\begin{tabular}{|c|c|}
\hline $\begin{array}{l}\text { The name of } \\
\text { classes }\end{array}$ & Foresight methods belonging to each class \\
\hline Consultative & Voting, Polling, Survey, Interviews, Expert Panels, Essays, Conferences, Workshops, Citizen Panels, Brainstorming \\
\hline Creative & $\begin{array}{l}\text { Wild Cards, Mindmapping, Lateral Thinking, Futures Wheel, Role Play, Business Wargaming, Synectics, } \\
\text { Speculative Writing, Visualization, Metaphors, Assumption Reversal }\end{array}$ \\
\hline Prescriptive & $\begin{array}{l}\text { Relevance Trees, Morphological Analysis, Rich Pictures, Divergence Mapping, Future Mapping, Backcasting, } \\
\text { SRI Matrix, Science Fiction Analysis, Incasting, Genius Forecasting, Futures Biographies, TRIZ, Future History, } \\
\text { Alternative History }\end{array}$ \\
\hline Multicriterial & $\begin{array}{l}\text { Key Technologies, Source Data Analysis, Migration Analysis, Shift-Share Analysis, DEA, Factor Analysis, } \\
\text { Correspondence Analysis, Cluster Analysis, Sensitivity Analysis, AHP, Input-Output Analysis, Prioritization, } \\
\text { SMART, PRIME, MCDM }\end{array}$ \\
\hline Radar & $\begin{array}{l}\text { Scientometrics, Webometrics, Patent Analysis, Bibliometrics, Technological Substitution, S-Curve Analysis } \\
\text { Technology Mapping, Analogies }\end{array}$ \\
\hline Simulation & $\begin{array}{l}\text { Probability Trees, Trend Extrapolation, Long Wave Analysis, Indicators, Stochastic Forecast, Classification Trees, } \\
\text { Modeling and Simulation, System Dynamics, Agent Modeling }\end{array}$ \\
\hline Diagnostic & $\begin{array}{l}\text { Object Simulation, Force Field Analysis, Word Diamond, SWOT, STEEPVL, Institutional Analysis, DEGEST, Trial } \\
\text { \& Error, Requirement Analysis, Theory of Constraint, Issue Management, ANKOT }\end{array}$ \\
\hline Analytical & $\begin{array}{l}\text { SOFI, Stakeholder Analysis, Cross-Impact Analysis, Trend Impact Analysis, Structural Analysis, Megatrend } \\
\text { Analysis, Critical Influence Analysis, Technology Barometer, Cost-Benefit Analysis, Technology Scouting, } \\
\text { Technology Watch, Sustainability Analysis, Environmental Scanning, Content Analysis, FMEA, Risk Analysis, } \\
\text { Benchmarking }\end{array}$ \\
\hline Survey & $\begin{array}{l}\text { Web Research, Desk Research, Technology Assessment, Social Network Analysis, Literature Review, Weak Signals, } \\
\text { Retrospective Analysis, Macrohistory, Back-View Mirror Analysis }\end{array}$ \\
\hline Strategic & $\begin{array}{l}\text { Technology Roadmapping, Technology Positioning, Delphi, Scenarios, Social Impact Assessment, RPM Screening, } \\
\text { Technological Scanning, Multiple Perspectives Assessment, Causal Layered Analysis, MANOA, Action Learning }\end{array}$ \\
\hline
\end{tabular}

sides the many factors influencing the foresight research process) [Magruk, 2015]. Examples of specific technological areas are presented in the fourth row, based on research [Watson, Cupani, 2018] at Imperial Tech Foresight in the form of the "Table of Disruptive Technologies". Individual examples of technologies were selected on the basis of the time horizon postulated by Imperial Tech Foresight researchers and the availability of knowledge about them.

The first column of Table 3 refers to cryptocurrency technology. It is believed that for the fourth industrial revolution to be successful, an open, borderless, payment protocol in the form of bitcoin (one of the most popular cryptocurrencies) must be in place [GilPulgar, 2016]. Postulated foresight research methods, which are possible to apply in this case are interviews, expert panels, genius forecasting, megatrend analysis, essays, and literature reviews. The use of the first three methods is reflected in the opinion of Klaus Schwab, Founder and Executive Chairman of the World Economic Forum, which stated that "bitcoin's blockchain is the heart of Industry 4.0" [Gil-Pulgar, 2016]. The relationship "Zero scope of uncertainty in nomological knowledge vs. predicted future" with respect to the discussed technology seems to be a correct evaluation.

Key technological components of Industry 4.0 alongside wearables (e.g., smart glasses), augmented reality applications, distributed ledger systems (e.g., the blockchain), big data analytics as well as autonomous vehicles (including multi-agent systems) make up the second column. According to scientometrics and desk research (the recommended foresight methods in this group), autonomous vehicles are important in two dimensions of Industry 4.0: internal transport (within smart factories, e.g. via trailer unloading or piece picking robots) as well as external transport (e.g. via autonomous trucks, drones). Specific for this column, the surface scope of uncertainty refers to certain described tendencies in the literature [Hermann et al., 2016; Hofmann, Rüsch, 2017; Lom et al., 2016]. With regard to the third column in Table 3 (on the basis of web research), according to EIT Digital, a leading European digital innovation and entrepreneurial education organization (and other statistical studies), avatar companions (e.g., chatbots, assistants of engineers) are becoming increasingly widespread, both on the consumer market and in industrial applications. There is a growing interest in using chatbots to support collaboration between people and machines in industrial processes, and some industries, such as IBM, see this as a step towards Industry 4.0 [Saracco, 2018; Jassova, 2019]. In Industry 4.0, the data analysis performed by an avatar in the form of a chatbot can provide quick insight into emerging problems and easily translate them into a format that is understandable not only to machines but also to people [Boker, 2019].

Four-dimensional materials (fourth column) are a type of smart materials created (being at an early stage of development) as part of a process called additive manufacturing (current knowledge according to Table 3). In this case, 3D materials (now very popular in the development of Industry 4.0) are enriched with an additional dimension - time/memory. The implementation of this kind of material as part of 
Table 3. Methodological Foresight Matrix in Relation to Futures, Uncertainties, and Knowledge (with samples of technologies related to Industry 4.0)

\begin{tabular}{|c|c|c|c|c|c|c|c|c|c|}
\hline \multicolumn{10}{|c|}{ Time } \\
\hline $\begin{array}{l}\text { TYPE OF FU- } \\
\text { TURE }\end{array}$ & $\begin{array}{l}\text { Predict- } \\
\text { ed (a) }\end{array}$ & $\begin{array}{l}\text { Projected } \\
\text { (a) }\end{array}$ & $\begin{array}{l}\text { Probable } \\
\text { (a) }\end{array}$ & $\begin{array}{l}\text { Plausible } \\
\text { (b) }\end{array}$ & $\begin{array}{l}\text { Pictured } \\
\text { (c) }\end{array}$ & $\begin{array}{l}\text { Possible } \\
\text { (e) }\end{array}$ & $\begin{array}{l}\text { Preposterous } \\
\text { Future (e) }\end{array}$ & $\begin{array}{l}\text { Potential } \\
\text { Future }\end{array}$ & $\begin{array}{l}\text { Preferable } \\
\text { / Desirable } \\
\text { Future } \\
\end{array}$ \\
\hline $\begin{array}{l}\text { SCOPE OF } \\
\text { UNCER- } \\
\text { TAINTY }\end{array}$ & Zero & Surface & Statistical & Scenario & Outspread & $\begin{array}{l}\text { Substan- } \\
\text { tial }\end{array}$ & Deep & Absolute & $\begin{array}{l}\text { Combination } \\
\text { of personal } \\
\text { uncertainties }\end{array}$ \\
\hline $\begin{array}{l}\text { LEVEL } \\
\text { (AWARE- } \\
\text { NESS) OF } \\
\text { KNOWL- } \\
\text { EDGE }\end{array}$ & $\begin{array}{l}\text { Nomo- } \\
\text { logical }\end{array}$ & Plain & $\begin{array}{l}\text { Based on } \\
\text { Current } \\
\text { Trends }\end{array}$ & $\begin{array}{c}\text { Based on } \\
\text { Current } \\
\text { Knowledge }\end{array}$ & Borrowed & Blurry & Irrational & $\begin{array}{l}\text { Total Ig- } \\
\text { norance }\end{array}$ & $\begin{array}{l}\text { Combination } \\
\text { of expert's } \\
\text { knowledge }\end{array}$ \\
\hline $\begin{array}{l}\text { SAMPLES } \\
\text { OF TECH- } \\
\text { NOLOGIES } \\
\text { RELATED TO } \\
\text { INDUSTRY } \\
4.0\end{array}$ & $\begin{array}{l}\text { Crypto- } \\
\text { curren- } \\
\text { cies }\end{array}$ & $\begin{array}{l}\text { Delivery } \\
\text { by au- } \\
\text { tonomous } \\
\text { vehicles }\end{array}$ & $\begin{array}{l}\text { Avatar } \\
\text { compan- } \\
\text { ions }\end{array}$ & $\begin{array}{l}\text { 4-dimen- } \\
\text { sional ma- } \\
\text { terials }\end{array}$ & $\begin{array}{l}\text { Swarm ro- } \\
\text { botics }\end{array}$ & $\begin{array}{l}\text { Trans- } \\
\text { human } \\
\text { technolo- } \\
\text { gies }\end{array}$ & $\begin{array}{l}\text { Artificial } \\
\text { conscious- } \\
\text { ness }\end{array}$ & $?$ & $\begin{array}{l}\text { Innovative } \\
\text { technologies }\end{array}$ \\
\hline $\begin{array}{l}\text { CLASSES OF } \\
\text { FORESIGHT } \\
\text { METHODS }\end{array}$ & \multicolumn{9}{|c|}{$\begin{array}{l}\text { SAMPLES OF FORESIGHT METHODS BELONGING TO EACH CLASS THAT CAN BE USED IN A SELECTED } \\
\text { SCOPE OF UNCERTAINTY, TYPES OF FUTURE and LEVEL (AWARENESS) OF KNOWLEDGE }\end{array}$} \\
\hline Consultative & $\begin{array}{l}\text { Expert } \\
\text { Panels }\end{array}$ & & Survey & $\begin{array}{l}\text { Confer- } \\
\text { ences }\end{array}$ & Interviews & $\begin{array}{l}\text { Work- } \\
\text { shops }\end{array}$ & Essays & $\begin{array}{l}\text { Expert } \\
\text { Panels }\end{array}$ & \multirow{10}{*}{$\begin{array}{l}\text { A combina- } \\
\text { tion of se- } \\
\text { lected meth- } \\
\text { ods from } \\
\text { individual } \\
\text { classes }\end{array}$} \\
\hline Creative & & $\begin{array}{l}\text { Mind- } \\
\text { mapping }\end{array}$ & $\begin{array}{l}\text { Futures } \\
\text { Wheel }\end{array}$ & Metaphors & $\begin{array}{l}\text { Visualiza- } \\
\text { tion }\end{array}$ & $\begin{array}{l}\text { Wild } \\
\text { Cards }\end{array}$ & $\begin{array}{l}\text { Speculative } \\
\text { Writing }\end{array}$ & & \\
\hline Prescriptive & $\begin{array}{l}\text { Genius } \\
\text { Fore- } \\
\text { casting }\end{array}$ & TRIZ & $\begin{array}{l}\text { Morpho- } \\
\text { logical } \\
\text { Analysis }\end{array}$ & $\begin{array}{l}\text { Relevance } \\
\text { Trees }\end{array}$ & $\begin{array}{l}\text { Future } \\
\text { Mapping }\end{array}$ & $\begin{array}{l}\text { Rich Pic- } \\
\text { tures }\end{array}$ & $\begin{array}{l}\text { Alternative } \\
\text { History, Sci- } \\
\text { ence Fiction }\end{array}$ & $\begin{array}{l}\text { Genius } \\
\text { Forecast- } \\
\quad \text { ing }\end{array}$ & \\
\hline Multicriterial & & AHP & DEA & $\begin{array}{l}\text { Key Tech- } \\
\text { nologies }\end{array}$ & $\begin{array}{c}\text { Cluster } \\
\text { Analysis }\end{array}$ & & & & \\
\hline Radar & $\begin{array}{l}\text { Patent } \\
\text { Analy- } \\
\text { sis }\end{array}$ & $\begin{array}{l}\text { Sciento- } \\
\text { metrics }\end{array}$ & $\begin{array}{l}\text { Webomet- } \\
\text { rics }\end{array}$ & $\begin{array}{l}\text { Technol- } \\
\text { ogy Map- } \\
\text { ping }\end{array}$ & & & & Analogies & \\
\hline Simulation & & $\begin{array}{l}\text { Trend } \\
\text { Extrapola- } \\
\text { tion }\end{array}$ & $\begin{array}{c}\text { Probabil- } \\
\text { ity Trees, } \\
\text { Stochastic } \\
\text { Forecast }\end{array}$ & $\begin{array}{l}\text { Classifica- } \\
\text { tion Trees }\end{array}$ & $\begin{array}{l}\text { Modeling } \\
\text { and Simu- } \\
\text { lation }\end{array}$ & & $\begin{array}{l}\text { Long Wave } \\
\text { Analysis }\end{array}$ & $\begin{array}{l}\text { System } \\
\text { Dynam- } \\
\text { ics }\end{array}$ & \\
\hline Diagnostic & & STEEPVL & $\begin{array}{l}\text { Force Field } \\
\text { Analysis }\end{array}$ & $\begin{array}{l}\text { SWOT, } \\
\text { DEGEST }\end{array}$ & $\begin{array}{c}\text { Object } \\
\text { Simulation }\end{array}$ & & & & \\
\hline Analytical & $\begin{array}{l}\text { Mega- } \\
\text { trend } \\
\text { Analy- } \\
\text { sis }\end{array}$ & $\begin{array}{l}\text { Cross- } \\
\text { Impact } \\
\text { Analysis }\end{array}$ & $\begin{array}{l}\text { Trend } \\
\text { Impact } \\
\text { Analysis }\end{array}$ & $\begin{array}{l}\text { Content } \\
\text { Analysis }\end{array}$ & $\begin{array}{l}\text { Bench- } \\
\text { marking }\end{array}$ & & & $\begin{array}{l}\text { Tech- } \\
\text { nology } \\
\text { Watch, } \\
\text { Environ- } \\
\text { mental } \\
\text { Scanning }\end{array}$ & \\
\hline Survey & $\begin{array}{l}\text { Litera- } \\
\text { ture Re- } \\
\text { view }\end{array}$ & $\begin{array}{l}\text { Desk Re- } \\
\text { search }\end{array}$ & $\begin{array}{l}\text { Web Re- } \\
\text { search }\end{array}$ & $\begin{array}{l}\text { Technol- } \\
\text { ogy Assess- } \\
\text { ment }\end{array}$ & $\begin{array}{l}\text { Social } \\
\text { Network } \\
\text { Analysis }\end{array}$ & $\begin{array}{l}\text { Weak } \\
\text { Signals }\end{array}$ & Macrohistory & & \\
\hline Strategic & & $\begin{array}{l}\text { Techno- } \\
\text { logical } \\
\text { Scanning }\end{array}$ & Delphi & Scenarios & $\begin{array}{l}\text { Roadmap- } \\
\text { ping }\end{array}$ & MANOA & $\begin{array}{c}\text { RPM } \\
\text { Screeening }\end{array}$ & & \\
\hline
\end{tabular}

Industry 4.0 provides advantageous features like the reconfiguration of the printed structure and attaining the desired material property in time (current knowledge in relation to Table 3). Sectors which, within the framework of Industry 4.0's development, have plausible potential (with a scenario scope of uncertainty) to implement 4D materials including: medical engineering, clothing industry, and jewelry applica- tions, power engineering, soft robotics, and the space industry [Dilberoglu et al., 2017].

The concept of "swarm robotics" - fifth column - is based on the use of a large number (tens, hundreds) of simple machines for complex tasks. With simple rules and local interactions, swarm robots aim to design robust, scalable, and flexible collective behaviors to coordinate a large number of robots. The inspiration 
to explore the possibilities of swarm robot is most often provided by the self-organized nature (similarly as in the case of biomimicry [Passino, 2005]) in the form of colonies of ants, bees, birds, fish, and others (borrowed knowledge). The potential of "swarm robotics" in relation to the idea of Industry 4.0 lies in modular solutions, for example, in shape-changing machines (as in The Terminator movie) (pictured future) or programmable matter as an alternative to $3 \mathrm{D}$ printing. The advantage of swarm robots is their autonomy or cooperation in tackling a given task. The lack of operation of a small number of robots does not automatically mean the failure of the whole task. However, the described idea is also associated with a lot of difficulties of an algorithmic, technical, and financial nature. The fact that swarm robots do not have access to centralized control and/or to global knowledge [Brambilla et al., 2013] is also a debatable issue in the context of the development of Industry 4.0 (outspread uncertainty).

Transhuman technologies (sixth column) will enable machines and living organisms to function at a high level of symbiosis (such as, e.g., by connecting human brains to global/internet databases). According to the visionaries, this integration is possible thanks to the achievements of genetics, cyber-technology, nanotechnology, biotechnology, artificial intelligence, and other areas [McIntosh, 2010]. In this case, the concept of Industry 4.0 strongly corresponds to the idea of the so-called "web of things" (web 4.0) [Muller, 2008]. This is the vision that will lead to [Sarowski, 2017]:

1) highly developed interactions taking place in symbiosis between man and machine;

2) integration into the network of almost all kinds of devices - through the full realization of the concept of the Internet of Things;

3) a new type of communication both in connecting people to objects and in connecting objects themselves to each other.

The substantial scope of uncertainty in blurry knowledge and potential future refers to the idea of creating a new generation of people (super-humans) by reaching a new level of their evolution. This idea is burdened with a high level of critical problems of security, which makes it necessary to apply such foresight methods as wild cards, rich pictures, and weak signals in this phase. It is an idea of the world in which man still plays a significant role despite the ubiquitous presence of technology, similar to the idea of Industry 5.0 [Skobelev, Borovik, 2017; Guttman et al., 2017].

Artificial consciousness refers to the construction of intelligent machines that can compete with human intelligence. From today's point of view, it is a highlevel science fiction idea. Therefore, we are dealing with a deep scope of uncertainty, in many aspects with irrational knowledge and a preposterous fu- ture. This approach raises the following philosophical questions: Can computers think? Is consciousness a human privilege? Can computer hardware replicate consciousness? (which is often regarded as the aspect of the mind that is least susceptible to artificial intelligence [Chrisley, 2008]). The answer to these questions is difficult because it requires a combination of information from many disciplines, including computer science, neurophysiology, philosophy, and religion [Buttazzo, 2001]. This requires the use of foresight research methods such as essays, speculative writing, alternative history, science fiction analysis, and macrohistory. In the context of the development of Industry 4.0, artificial consciousness strongly corresponds to the idea of the fifth generation of Internet development called the "web of thoughts" in the form of such technologies as: collective intelligence, artificial brain, digital aura - which allows for the intentional and adaptive behavior of autonomous robots - their body could be seen for itself as the morphologic apprehension of its material substrata [Cardon, 2006]. The role of the human element in this case is limited to a zero level.

In the last column, a combination of selected methods from individual classes depending upon the type of the desirable future can be created. The type of the desirable future depends upon the combination of the $a, b, c, d$, and e areas. A specific variation of the desirable future is the preferable future when we are dealing with sum of all areas $(a+b+c+d+e)$. Other combinations (pairs, triples, fours) are desirable futures. The number of possible combinations of types of futures is 25 . But the number of the possible combination of methods that we can use in research is very huge. For example, by combining any six methods (out of 116 methods identified by the author of this article) over three billion connections can be obtained [Magruk, 2013].

\section{Discussion}

The types of future (predicted, projected, probable, plausible, pictured, possible, preposterous, potential) and scope of uncertainty (zero, surface, statistical, scenarios, outspread, substantial, deep, absolute) proposed by the author based on the literature allow one to define the author's scale of knowledge levels in the form of: nomological, plain, based on current trends, based on current knowledge, borrowed, blurry - referring to future knowledge, irrational, and total ignorance.

The matrix of uncertainties, futures, and knowledge model has several modifications made by the author compared to the Voros model from:

- a new kind of future named the "pictured future";

- divisions of preferable future into sub-areas: $a, b$, c, d, e, characteristic for particular types of un- 
certainty and types of knowledge, which becomes preferable only with a specific configuration of factors as the future sum: from a to e, while other combinations receive the desirable form of future, which is characteristic in foresight research.

Such a schematic approach, although simplified, was a good basis for achieving the main purpose of the article, that is, to answer the question: "What is the methodical relationship between the scope of the uncertainty phenomenon and the levels of knowledge and types of futures in the foresight approach?"

The methodological approach presented in this publication may be valuable from several perspectives. On the one hand, it allows one to develop basic research through in-depth theoretical analysis. On the other hand, it is a new contribution to the development of foresight research methodology. Thirdly, it allows one to better recognize new, complex, but not yet fully developed phenomena such as Industry 4.0. Other areas worthy of methodological analysis from the point of view of foresight, uncertainty, and knowledge are, for example, the Internet of Everything, Industry X.0, Industry/WEB 5.0, strong artificial intelligence, and others.

\section{Conclusions}

According to the author, thanks to specific foresight methods from different classes (and/or their combinations) related to selected types of the future, it is possible to manage selected ranges of uncertainty and not only treat uncertainty as a background for futures studies.

This paper has attempted to draw together three methodological fields: uncertainty, foresight, and knowledge. The author analyzed the complex relationships among the above areas on the basis of their characteristics which are the author's extensions of existing concepts available in the literature. By showing the strong relationships between the above fields, the research objective of this work was achieved.

The most characteristic aspect of the foresight research methodology is the selection of appropriate research methods to create a desirable future. In the author's opinion, the results showed in this paper can be helpful in choosing appropriate foresight methods in a situation when we know with which type of future, scope of uncertainty, and level of knowledge we are dealing.

\section{References}

Abood D., Quilligan A., Narsalay R. (2017) Industry X.0 Combine and Conquer: Unlocking the Power of Digital, Dublin: Accenture. Available at: https:// www.accenture.com, accessed 11.12.2019.

Amara R. (1974) The futures field: Functions, forms, and critical issues. Futures, vol. 6, no 4, pp. 289-301. DOI:10.1016/00163287(74)90072-X.

Ansari F., Erol S., Sihn W. (2018) Rethinking Human-Machine Learning in Industry 4.0: How Does the Paradigm Shift Treat the Role of Human Learning?. Procedia Manufacturing, vol. 23, pp. 117-122.

Atherton J.S. (2013) Doceo. Knowing and not knowing. Available at: http://www.doceo.org.uk/tools/knowing.htm, accessed 25.09.2019.

Aven T. (2010) On how to define, understand and describe risk. Reliability Engineering and System Safety, vol. 95, no 6, pp. 623-631.

Aven T. (2013) Practical implications of the new risk perspectives. Reliability Engineering and System Safety, no 115, pp. 136-145.

Bereziński M., Hołubiec J. (1981) Podejmowanie decyzji w warunkach niepewności informacyjnej [Decision making under conditions of information uncertainty]. Metody modelowania i optymalizacji systemów energetycznych w warunkach niepewności [Methods for modeling and optimization of energy systems in conditions of uncertainty] (ed. W. Bojarski), Wrocław: PAN, Ossolineum, pp. 64-78 (in Polish).

Bojarski W. (1981) Zagadnienia nieokreśloności wielkich systemów i niepewności [Indeterminacy issues of great systems and uncertainties]. Metody modelowania i optymalizacji systemów energetycznych w warunkach niepewności (ed. W. Bojarski), Wrocław: PAN, Ossolineum, pp. 7-28 (in Polish).

Boker A. (2019) Industry 4.0: How Chatbot Data Analytics are Helping to Shape the Internet of Things within Telecommunications. Available at: https://www.glassboxdigital.com/learn-about-chatbot-data-analytics/, accessed 01.10.2019.

Bombola P. (2014) Uogólniona niepewność zewnętrzna i wewnętrzna [General external and internal uncertainty]. Ekonomia i Zarządzanie, vol. 6, no 1, pp. 127-141 (in Polish).

Brambilla M., Ferrante E., Birattari M., Dorigo M. (2013) Swarm robotics: A review from the swarm engineering perspective. Swarm Intelligence, vol. 7, no 1, pp. 1-41.

Buttazzo G. (2001) Artificial consciousness: Utopia or real possibility?. Computer, vol. 34, no 7, pp. 24-30.

Candy S. (2010) The futures of everyday life: Politics and the design of experiential scenarios, Honolulu, HI: University of Hawaii at Manoa. 
Cardon A. (2006) Artificial consciousness, artificial emotions, and autonomous robots. Cognitive Processing, vol. 7, no 4, pp. 245-267.

Chodakowska E., Nazarko J. (2017) Environmental DEA method for assessing productivity of European countries. Technological and Economic Development of Economy, vol. 23, no 4, pp. 589-607.

Chrisley R. (2008) Philosophical foundations of artificial consciousness. Artificial Intelligence in Medicine, vol. 44, no 2, pp. 119-137.

Cividino S., Egidi G., Zambon I., Colantoni A. (2019) Evaluating the Degree of Uncertainty of Research Activities in Industry 4.0. Future Internet, vol. 11, no 9, article 196, pp. 1-21. Available at: https://www.researchgate.net/publication/335765945_ Evaluating_the_Degree_of_Uncertainty_of_Research_Activities_in_Industry_40/fulltext/5d7a43fca6fdcca980e1bbd6/ Evaluating-the-Degree-of-Uncertainty-of-Research-Activities-in-Industry-40.pdf, accessed 24.01.2020.

Courtney H. (2001) 20/20 Foresight: Crafting strategy in an uncertain world, Boston, MA: Harvard Business Press.

Courtney H., Kirkland J., Viguerie P. (1997) Strategy under Uncertainty. Harvard Business Review, vol. 75, no 6, pp. 67-79.

Dilberoglu U.M., Gharehpapagh B., Yaman U., Dolen M. (2017) The role of additive manufacturing in the era of industry 4.0. Procedia Manufacturing, vol. 11, pp. 545-554.

Funtowicz S.O., Ravetz J.R. (1990) Uncertainty and quality in science for policy, Heidelberg, New York, Dordrecht, London: Springer Science \& Business Media.

Gaweł B., Rębiasz B., Skalna I. (2015) Teoria prawdopodobieństwa i teoria możliwości w podejmowaniu decyzji inwestycyjnych [Probability theory and possibility theory in investment decision making]. Studia Ekonomiczne, vol. 248, pp. 62-79 (in Polish).

Gil-Pulgar J. (2016) Bitcoin: Welcome to the Fourth Industrial Revolution. Available at: https://news.bitcoin.com/bitcoinfourth-industrial-revolution/, accessed 15.10.2019.

Guimaraes Pereira A., von Schomberg R., Funtowicz S. (2006) Foresight knowledge assessment. International Journal of Foresight and Innovation Policy, vol. 3, no 1, pp. 53-75.

Guttman U., Papst J., Merlo R., Kane D., Bieser G., Grob O. (2017) Industry 4.0: What's Next. An SAP Point of View. SAP White Paper. Available at: https://www.sap.com/documents/2017/05/bae613d3-b97c-0010-82c7-eda71af511fa.html, accessed 23.01.2020.

Hancock T., Bezold C. (1994) Possible futures, preferable futures. Healthcare Forum Journal, vol. 37, no 2, pp. $23-29$.

Hariri R.H., Fredericks E.M., Bowers K.M. (2019) Uncertainty in big data analytics: Survey, opportunities, and challenges. Journal of Big Data, vol. 6, no 1, article 44 (online). Available at: https://www.springerprofessional.de/content/ pdfId/16778576/10.1186/s40537-019-0206-3, accessed 24.01.2020.

Hawking S.W. (1988) A Brief History of Time: From the Big Bang to Black Holes, New York: Bantam Dell Publishing Group.

Heller M. (2016) Filozofia przypadku [Philosophy of Chance], Kraków: Coperncus Center Press (in Polish).

Hermann M., Pentek T., Otto B. (2016) Design principles for industrie 4.0 scenarios. Proceedings of the 201649 th Hawaii international conference on system sciences (HICSS), Piscataway, NJ: IEEE, pp. 3928-3937.

Hofmann E., Rüsch M. (2017) Industry 4.0 and the current status as well as future prospects on logistics. Computers in Industry, vol. 89, pp. 23-34.

Inayatullah S. (2008) Six pillars: Futures thinking for transforming. Foresight, vol. 10, no 1, pp. 4-21.

Jalonen H. (2012) The Uncertainty of Innovation: A Systematic Review of the Literature. Journal of Management Research, vol. 4, no 1, pp. 1-47. DOI: 10.5296/jmr.v4i1.1039.

Janasz K. (2009) Ryzyko i niepewność w gospodarce - wybrane aspekty teoretyczne [Risk and Uncertainly in Economy Choosen Theoretical Aspects]. Studia i Prace Wydziału Nauk Ekonomicznych i Zarzadzania, vol. 14, pp. 87-98 (in Polish).

Jassova B. (2019) Chatbot Statistics Compilation 2019: The State of Market \& Business Opportunities. Available at: https:// landbot.io/blog/chatbot-statistics-compilation/, accessed 29.09.2019.

Jędralska K., Czech A. (2011) O naturze niepewności i jej interpretacjach [The nature of uncertainty and its interpretations]. Master of Business Administration, vol. 19, no 3, pp. 9-18 (in Polish).

Jemala M. (2010) Evolution of foresight in the global historical context. Foresight, vol. 12, no 4, pp. 65-81.

Jenssen S. (2010) Foresight between uncertainty and convention: An ethnographic study of research policy foresight at the Research Council of Norway (PhD thesis), Oslo: University of Oslo.

Kaivo-oja J.Y., Katko T.S., Seppala O.T. (2004) Seeking convergence between history and futures research. Futures, no 36, pp. 527-547.

Kononiuk A., Nazarko J. (2014) Scenariusze w antycypowaniu i kształtowaniu przyszłości [Scenarios for anticipating and shaping the future], Warszawa: Wolters Kluwer (in Polish).

Kononiuk A., Sacio-Szymańska A., Gáspár J. (2017) How do companies envisage the future? Functional foresight approaches. Engineering Management in Production and Services, vol. 9, no 4, pp. 21-33.

Larsen S.C. (2006) The Future's Past: Politics of Time and Territory among Dakelh First Nations in British Columbia. Geografiska Annaler: Series B, Human Geography, vol. 88, no 3, pp. 311-321. Available at: https://doi.org/10.1111/j.14680459.2006.00224.x, accessed 19.01.2020. 
Lindley D.V. (2013) Understanding Uncertainty, Hoboken, NJ: John Wiley \& Sons, Inc.

Lom M., Pribyl O., Svitek M. (2016) Industry 4.0 as a part of smart cities. Proceedings of the 2016 Smart Cities Symposium Prague (SCSP), 26-27 May 2016 (ed. M. Koukol), Piscataway, NJ: IEEE, pp. 22-27.

Magnus S. (2012) Exploratory or normative: New show. Adventure future. Stephmag, 27.02.2012. Available at: http:// adventurefuture.wordpress.com/2012/02/27/exploratory-or-normative-new-show/, accessed 14.10.2019.

Magruk A. (2011) Innovative classification of technology foresight methods. Technological and Economic Development of Economy, vol. 17, no 4, pp. 700-716.

Magruk A. (2013) Hybrid concept in foresight methodology. Paper presented at The XXIV ISPIM Conference - Innovating in Global Markets: Challenges for Sustainable Growth in Helsinki, Finland, 16-19 June 2013. Available at: https:// search.proquest.com/openview/bc729a2c014ecc2e2b45d0704766d8eb/1?pq-origsite=gscholar\&cbl=1796422, accessed 16.01.2020.

Magruk A. (2015) The Most Important Aspects of Uncertainty in the Internet of Things Field - Context of Smart Buildings. Procedia Engineering, vol. 122, pp. 220-227. DOI: 10.1016/j.proeng.2015.10.028.

Magruk A. (2016) Uncertainty in the sphere of the industry 4.0 - potential areas to research. Business, Management and Education, vol. 14, no 2, pp. 275-291.

Magruk A. (2017a) Concept of uncertainty in relation to the foresight research. Engineering Management in Production and Services, vol. 9, no 1, pp. 46-55.

Magruk A. (2017b) Phenomenon of Uncertainty in the Process of Holistic Anticipation of Non-deterministic Reality. Procedia Engineering, vol. 182, pp. 434-442.

McIntosh D. (2010) The transhuman security dilemma. Journal of Evolution and Technology, vol. 21, no 2, pp. 32-48.

Muller N. (2008) The Web Expansion. From Web of Things to Web of Thoughts. Available at: www.trendone.de, accessed 21.10.2019.

Nahavandi S. (2019) Industry 5.0 - A Human-Centric Solution. Sustainability, vol. 11, no 16, article 4371, pp. 1-13. Available at: https://www.researchgate.net/publication/335148344_Industry_50-A_Human-Centric_Solution, accessed 24.01.2020.

Njå O., Solberg Ø., Sverre Braut G. (2017) Uncertainty - Its Ontological Status and Relation to Safety. The Illusion of Risk Control. What Does it Take to Live With Uncertainty? (eds. G. Motet, C. Bieder), Heidelberg, New York, Dordrecht, London: Springer, pp. 5-21. Available at: https://link.springer.com/chapter/10.1007/978-3-319-32939-0_2, accessed 19.12.2019.

Passino K.M. (2005) Biomimicry for optimization, control, and automation, Heidelberg, New York, Dordrecht, London: Springer Science \& Business Media.

Pieriegud J. (2015) Wykorzystanie megatrendów do analizy przyszłościowego rozwoju sektorów gospodarki [Using megatrends to analyse the future development of economic sectors]. Megatrendy $i$ ich wpływ na rozwój sektorów infrastrukturalnych [Megatrends and their impact on the development of infrastructure sectors] (eds. J. Gajewski, W. Paprocki, J. Pieriegud), Gdańsk: Instytut Badań nad Gospodarką Rynkową - Gdańska Akademia Bankowa, pp. 8-25 (in Polish).

Poli R. (2017) Introduction to Anticipation Studies, vol. 1, Heidelberg, New York, Dordrecht, London: Springer International Publishing.

Refsgaard J.C., Arnbjerg-Nielsen K., Drews M., Halsnæs K., Jeppesen E., Madsen H., Markandya A., Olesen J.E., Porter J.R., Christensen J.H. (2013) The role of uncertainty in climate change adaptation strategies - A Danish water management example. Mitigation and Adaptation Strategies for Global Change, vol. 18, no 3, pp. 337-359.

Ringland G. (1998) Scenario planning: Managing for the future, Chichester: John Wiley \& Sons.

Samecki W. (1967) Ryzyko i niepewność w działalności przedsiębiorstwa przemysłowego [Risks and uncertainties in the activity of an industrial enterprise], Warszawa: Państwowe Wydawnictwo Ekonomiczne (in Polish).

Saracco R. (2018) Disruptive Technologies beyond 2030 for Human Machine Interactions. Available at: https://cmte.ieee.org, accessed 18.10.2019.

Sardar Z., Sweeney J.A. (2016) The three tomorrows of postnormal times. Futures, vol. 75, pp. 1-13.

Sarowski Ł. (2017) Od Internetu Web 1.0 do Internetu Web 4.0-ewolucja form przestrzeni komunikacyjnych w globalnej sieci [From Internet web 1.0 to Internet web 4.0 - the development of the communication space forms in the global network]. Rozprawy Społeczne, vol. 11, no 1, pp. 32-39 (in Polish).

Schaeffer E. (2017) Industry X. 0: Realizing digital value in industrial sectors, Munchen: Redline Verlag.

Schwartz P. (2012) Winning in an Uncertain Future through Scenario Planning. Delivering Tomorrow, Logistics 2050, A Scenario Study, Bonn: Deutsche Post AG, pp. 27-33.

Shepherd D.A., Suddaby R. (2017) Theory building: A review and integration. Journal of Management, vol. 43, no 1, pp. 59-86. Siderska J., Jadaan K.S. (2018) Cloud manufacturing: a service-oriented manufacturing paradigm. A review paper. Engineering Management in Production and Services, vol. 10, no 1, pp. 22-31.

Skobelev P.O., Borovik S.Y. (2017) On the way from Industry 4.0 to Industry 5.0: From digital manufacturing to digital society. Industry 4.0, vol. 2, no 6, pp. 307-311. 
Smithson M. (1989) Ignorance and uncertainty: Emerging paradigms, Heidelberg, New York, Dordrecht, London: SpringerVerlag.

Sokolov A., Chulok A. (2012) Dolgosrochnyi prognoz nauchno-tekhnologicheskogo razvitiya Rossii na period do 2030 goda: klyuchevye osobennosti i pervye rezul'taty [Russian science and technology foresight - 2030: Key features and first results], Foresight-Russia, vol. 6, no 1, pp. 12-25 (in Russian).

Taylor C.W. (1990) Creating strategic visions, Carlisle: Strategic Studies Institute, US ArmyWar College, Carlisle Barracks.

UNDP (2018) Foresight Manual. Empowered Futures for the 2030 Agenda, Singapore: UNDP Global Centre for Public Service Excellence.

van der Sluijs J.P. (1997) Anchoring amid uncertainty. On the management of uncertainties in risk assessment of anthropogenic climate change, Den Haag: CIF-Gegevens Koninklijke Bibliotheek.

Voros J. (2017) Big History and Anticipation. Handbook of Anticipation. Theoretical and Applied Aspects of the Use of Future in Decision Making (ed. R. Poli), Heidelberg, New York, Dordrecht, London: Springer, pp. 425-464. DOI: 10.1007/978-3319-31737-3_95-1.

Walker W.E., Harremoës P., Rotmans J., van der Sluijs J.P., van Asselt M.B., Janssen P., Krayer von Krauss M.P. (2003) Defining uncertainty: A conceptual basis for uncertainty management in model-based decision support. Integrated Assessment, vol. 4, no 1, pp. 5-17.

Watson R., Cupani A. (2018) Table of Disruptive-Technologies, London: Imperial College. Available at: https://www.imperial. ac.uk/media/imperial-college/administration-and-support-services/enterprise-office/public/Table-of-DisruptiveTechnologies.pdf, accessed 15.12.2019.

Wawiernia A. (2013) Taksonomia niepewności [Taxonomy of uncertainty]. Zarządzanie i Finanse, vol. 11, no 1/3, pp. 445-454 (in Polish). 